\title{
PENDIDIKAN KECAKAPAN HIDUP PADA REMAJA MASYARAKAT BAJO DESA SOROPIA, KONAWE
}

\author{
HERMAN ${ }^{1)}$, MOHAMAD RIJAL ${ }^{2)}$ \\ Fakultas Tarbiyah dan Ilmu Keguruan Institut Agama Islam Negeri Kendari \\ Koresponden Author: hermaniain59@gmail.com
}

\begin{abstract}
This study aims to investigate the teenagers' life of Bajo society in Bokori of Soropia, Konawe related to their life skill education. The results reveal that (1) the Bokori community in Soropia Konawe is generally very enthusiastic about the life skill the teenagers in this village. According to them, life education is very important because with these skills, they will be able to support the future and to solve and overcome the problems they face in life. (2) the implementation of life skills education for teenagers in Bokori is good enough. It is seen from the efforts made by parents who accustom their children to work from the early age, teach their children working theory and practice, and motivate them. In the implementation of the life skill education, there are several supportive factors, namely the existence of a network and cooperation with people and institutions that exist in Soropia, and their teachers are professionals. In addition, in the implementation of life skill education, there are also some obstacles, namely financial factors or funding which is the most important factor, lack of facilities and infrastructure, lazy teenagers, and limited time allocation. The efforts undertaken to overcome these obstacle are establishing the relationship and cooperation with the people and institutions that schools and offices, developing tolerance and guidance to teenagers, and maximizing existing activities. Unfortunately, most of teenagers prefer to work as sailorman because of the higher income that a handyman salary.
\end{abstract}

\section{Keyword: life skill education, Bajo community, teenager}

\begin{abstract}
Abstrak
Penelitian ini mengungkap potret kehidupan remaja masyarakat Bajo di Desa Bokori Kec. Soropia Kab. Konawe yang berhubungan dengan pendidikan kecakapan hidup mereka. Hasil penelitian menunjukan bahwa masyarakat Desa Bokori Kecamatan Soropia Kabupaten Konawe pada umumnya sangat antusias terhadap pendidikan kecapan hidup pada remaja yang dianggap dapat menunjang masa depan dan dapat memecahkan dan mengatasi permasalahan hidup yang dihadapinya. Oleh sebab itu, pendidikan kecakapan hidup pada remaja berjalan dengan cukup baik, yang terlihat dari upaya orang tua yang membiasakan bekerja sejak kecil, diajarakan teori dan praktek kerja dan diberikan motivasi. Faktor pendukung terlaksanan pendidikan kecakapan hidup ini disebabkan oleh, yaitu adanya jaringan dan kerja sama yang
\end{abstract}


baik dengan masyarakat dan lembaga-lembaga yang ada di wilayah Kecamatan Soropia, dan hadirnya pengajar yang profesional. Selain itu, hambatan yang dihadapi adalah faktor finansial atau pendanaan, sarana dan prasarana belum maksimal, remaja yang malas dan alokasi waktu. Berbagai upaya dilakukan untuk menanggulanginya, diantaranya adalah menjalin kerja sama dengan masyarakat dan lembaga-lembaga, yakni sekolah-sekolah dan kantor-kantor, sikap toleransi dan bimbingan terhadap remaja, dan memaksimalkan kegiatan yang ada.

\section{Kata Kunci : pendidikan kecakapan hidup, masyarakat Bajo, remaja.}

\section{A. PENDAHULUAN}

Kemajuan suatu bangsa ditentukan oleh kualitas sumber daya, baik sumber daya alam maupun sumber daya manusia. Kemajuan akan cepat dicapai bilamana didukung oleh sumber daya alam yang memadai dan sumber daya manusia yang berkualitas. Sebaliknya kemajuan akan terhambat jika faktor sumber daya alam dan sumber daya manusia relatif terbatas. Sumber daya alam merupakan sumber daya pasif, yang keberadaannya sangat tergantung pada kualitas sumber daya manusia yang mengelolanya. Apabila sumber daya manusia memiliki kualitas yang unggul maka sumber daya alam dapat diolah sedemikian rupa sehingga menyumbangkan manfaat dan kontribusi yang besar serta manfaat bagi pembangunan manusia Indonesia seutuhnya.

Pendidikan kecakapan hidup dapat membantu para remaja masyarakat Bajo untuk mengembangkan kemampuan belajar serta dapat menghilangkan kebiasaan-kebiasaan yang tidak berguna, seperti minum-minuman keras, berjudi, sabung ayam, mengganggu ketertiban masyarakat, mengambil barang yang bukan milikinya dan dapat pula merubah pola pikir yang lebih tepat dengan menyadari potensi diri untuk dapat dikembangkan serta diarahkan untuk berani menghadapi problem kehidupan serta dapat memecahkan segala permasalahan yang muncul. Pendidikan kecakapan hidup dimaksudkan untuk mengembangkan potensi yang ada pada diri para remaja masyarakat Bajo di Desa Bokori Kecamatan Soropia Kabupaten Konawe yang selama ini dipahami sebagai masyarakat laut. Pendidikan kecapakan hidup dilakukan agar anak memiliki keterampilan yang dapat menghidupi diri sendiri, dengan jalan menambah pengetahuan dan keterampilan dengan baik, serta mengedepankan dua tugas pokok yakni 1) pembentukan formal atau fungsional; dn 2) pembentukan secara material ${ }^{1}$.

Salah satu keterampilan yang mendasar dalam pendidikan kecakapan hidup yang dimiliki seseorang ialah kecakapan untuk berkomunikasi yang

${ }^{1}$ Purwanto, Ngalim, Ilmu Pendidikan Teori dan Praktis Edisi II (Bandung: PT Remaja Rosdakarya, 1995), h. 153. 
menunjang kecakapan bertanya, keinginan untuk mengetahui keterampilan yang dapat memenuhi kebutuhan, bukan saja untuk keluarga tetapi juga kebutuhan diri sendiri. Ahli filsafat, Gabril Marcel telah lama menyelidiki bahwa :

Hal pertama yang dipelajari anak yang baru lahir tidak hanya "saya ada" tetapi "kami ada" oleh karena itu saya ada. Jadi anak-anak dan orang dewasa mengalami dirinya dalam sebuah relaksi dan relasi yang ditanamkan lewat komunikasi ${ }^{2}$

Untuk mewujudkan hal ini, perlu diterapkan prinsip pendidikan berbasis luas yang tidak hanya berorientasi pada bidang akademik atau vokasional semata, tetapi juga memberikan bekal learning how to learn sekaligus learning how to unlearn, tidak hanya belajar teori, tetapi juga mempraktekkannya untuk memecahkan problema kehidupan sehari-hari.

Para remaja masyarakat Bajo di Desa Bokori Kecamatan Soropia Kabupaten Konawe, rata-rata memiliki kecakapan atau keterampilan hidup seperti membuat meja, kursi, lemari, tempat tidur dan menjahit. Tulisan ini akan mengulas tentang potret pendidikan kecakaan hidup pada remaja masyarakat Bajo Konawe Selatan pada aspek persepsi masyarakat Desa Bokori terhadap pendidikan kecakapan hidup anak pada remaja dan pelaksanaan pendidikan kecakapan hidup anak pada remaja masyarakat Bajo pada desa tersebut.

\section{B. PENDIDIKAN KECAPAKAN HIDUP PADA REMAJA B.1 Hakikat Remaja}

Beragam pendapat para pakar telah dipaparkan terkait dengan pengertian remaja. Menurut kamus bahasa Indonesia, remaja adalah usia yang masih muda, etape usia mulai dewasa atau sudah sampai umur untuk kawin ${ }^{3}$."

Masa remaja dipandang sebagai suatu masa dimana seorang mengalami tahap peralihan dari masa kanak-kanak ke masa dewasa, dengan asumsi bahwa untuk memasuki masa dewasa tampak ada satu semacam fase peralihan yang akhirnya disebut masa remaja. Dipandang sebagai masa peralihan karena seorang remaja tidak dapat disebut kanak-kanak karena adanya berbagai perubahan baik fisik ataupun psikis, tetapi ia belum cukup stabil untuk diperlukan sebagai orang dewasa. Dalam Islam dikenal istilah baligh, yang dapat diartikan sebagai periode dimana seorang bukan kanakkanak lagi atau mulai dewasa.

${ }^{2}$ Olen, Dale R, Kecakapan Hidup Pada Anak Bagaimana Mengajarkanya, diterjemahkan Hasto Rosa Riyanto, (Yogyakarta: Kanisius, 1987), h. 34.

${ }^{3}$ Santoso, Ananda, Kamus Praktis Bahasa Indonesia Untuk Pelajar dan Umum (Surabaya: Dara Publika, tth), h. 346. 
Ada beberapa periode yang dianggap lebih penting dari pada periode lainnya karena berakibat langsung terhadap sikap dan perilaku, dan ada yang diaggap penting karena berakibat jangka panjang. Pada periode peralihan, status individu tidak jelas dan terdapat keraguan akan peran yang harus dilakukan. Pada masa ini, remaja bukan lagi seorang anak dan juga bukan orang dewasa. Sehingga Andi Mappiere mengatakan bahwa Pada remaja sering terlihat adanya kegelisahan, pertentangan, berkeinginan besar untuk mencoba segala hal yang belum diketahunya, keinginan menjelajah ke alam sekitar yang lebih luas, menghayal dan berfantasi, serta aktivitas kelompok ${ }^{4}$.

Kegelisahan, pertentangan, berkeinginan besar dan lain sebagainya yang dialami oleh para remaja adalah merupakan cirri-ciri dan sifat yang selalu ada pada setiap anak yang menginjak pada usia remaja pada umumnya. Sehingga dalam sejarah kehidupan remaja sering dikatakan bahwa masa remaja adalah masa darah panas, sehingga setiap aktivitas yang menyalahi naorma-norma kemasyarakatan, agama dan negara yang dilakukan oleh remaja diidentikan dengan kenakalan remaja.

Selain itu, remaja juga mengalami perubahan sikap yang sejajar dengan perubahan fisik. Ketika perubahan fisik terjadi dengan pesat, perubahan perilaku dan sikap juga berlangsung pesat, dan sebaliknya. Ada lima perubahan yang sama yang hampir bersifat universal yang terjadi pada masa remaja, yakni:

1). Meningginya emosi yang intensitasnya bergantung pada tingkat perubahan fisik dan psikologis yang terjadi.

2). Perubahan-perubahan yang menyertai kematangan seksual membuat remaja tidak yakin akan dirinya, kemampuankemampuannya serta minatnya.

3). Perubahan tubuh, minat, dan peran yang diharapkan oleh lingkungan menimbulkan masalah baru bagi remaja.

4). Perubahan dalam minat dan perilaku disertai pula perubahan dalam nilai-nilai.

5). Sebagian remaja bersikap ambivalen terhadap setiap perubahan. Mereka ingin dan menuntut kebebasan tetapi sering takut bertanggung jawab akan akibatnya dan tidak yakin dengan kemampuannya untuk memikul tanggung jawab tersebut ${ }^{5}$.

Kelima perubahan tersebut di atas adalah merupakan prubahan yang terjadi pada remaja pada umumnya. Perubahan-perubahan tersebut sangat berdampak pada psikologi dan perilaku para remaja, sehingga dalam sebagian

\footnotetext{
${ }^{4}$ Mappiare, Andi, Psikologi Remaja (Surabaya: Usaha Nasional, 1982), h. 32.

${ }^{5}$ Soeparwoto, dkk., Psikologi Perkembangan, Cet. V, (Semarang: UPT MKK UNNES), h. 62.
} 
dari aktivitasn sehari-harinya sering terjadi konflik dalam kehidupannya, baik itu konflik terhadap dirinya sendiri, keluarga, teman-teman, tetangga maupun masyarakat sekitarnya.

\section{B.2 Hakikat Pendidikan Kecakapan Hidup (Life Skills)}

Dalam konteks pendidikan, belajar ketrampilan merupakan bagian dari hal yang cukup penting untuk dilaksanakan di masyarakat, baik yang bersifat kognitif, afektif maupun psikomotorik. Dimensi belajar ketrampilan ini lebih condong dan dominan pada aspek psikomotor. Pendidikan bertujuan untuk meningkatkan kualitas hidup manusia yang secara teknis operasional dilakukan melalui pembelajaran. Program pembelajaran yang baik akan menghasilkan efek berantai pada kemampuan anak untuk belajar secara terus menerus melalui lingkungannya (lingkungan alam dan lingkungan sosial) sebagai sumber belajar yang tidak terbatas. Keterampilan khusus yang dimaksud dalam life skills aspek life skills dapat diperoleh melalui keterampilan belajar.

Kecakapan hidup merupakan orientasi pendidikan yang mensinergikan pendidikan menjadi kecakapan hidup yang diperlukan seseorang, dimanapun ia berada, bekerja atau tidak bekerja, apapun profesinya. Secara harfiah kata "skills" dapat diterjemahkan dengan "ketrampilan" namun dalam konteks ini maknanya menjadi terlalu sempit atau konsepnya kurang luas dari makna yang sebenarnya" . Oleh karena itu, kata yang dipandang lebih memadai untuk menerjemahkan kata skills dalam konteks ini adalah kecakapan. Pendidikan kecakapan hidup atau life skills menurut tim broad based education Depdiknas bahwa Kecakapan hidup atau life skills adalah kecakapan yang dimiliki oleh seseorang untuk mau dan berani menghadapi problema hidup dan kehidupan secara wajar tanpa merasa tertekan, kemudian secara pro aktif dan kreatif dapat mencari serta menemukan solusi untuk mengatasi tuntutan hidupnya ${ }^{7}$.

Kecakapan hidup dapat dipilah menjadi dua jenis utama, yaitu kecakapan hidup yang bersifat generik (generic life skill) yang terbagi atas kecakapan personal (personal skill) dan kecakapan sosial (social skill) sedangkan kecakapan hidup yang bersifat khusus (specific life skill) mencakup kecakapan akademik (academic skill) dan kecakapan vokasional (vocational skill). Kecakapan hidup yang bersifat generik (generic life skill/GLS), yang mencakup:

a. Kecakapan personal (personal skill),

${ }^{6}$ Sumarni, Sri, Jurnal Ilmu Al-Qur'an Hadits, Kajian Tentang Konsep, Problem dan Prospek Al-Qur'an Hadits, (Yogyakarta: IAIN Sunan Kalijaga, 2002), h. 172.

${ }^{7}$ Anwar, Pendidikan Kecakapan Hidup, Konsep dan Aplikasi, (Bandung: CV Alfa Beta, 2004), h. 25. 
Yaitu kecakapan yang diperlukan bagi seseorang untuk mengenal dirinya secara utuh. Kecakapan ini mencakup kecakapan akan kesadaran diri atau memahami diri (self awareness) dan kecakapan berfikir (thinking skill), kecakapan berpikir rasional, dan percaya diri.

b. Kecakapan sosial (social skill)

Mencakup kecakapan melakukan kerja sama, bertenggang rasa dan bertanggung jawab sosial, berkomunikasi dengan empati (communication skill) dan kecakapan bekerja sama (collaboration skill).

c. Kecakapan akademik (academic skills), yaitu kecakapan dalam melakukan penelitian, percobaan-percobaan dengan menggunakan pendekatan ilmiah.

Tujuan pendidikan kecakapan hidup (life skill) adalah menyiapkan peserta didik agar yang bersangkutan mampu, sanggup, dan terampil menjaga kelangsungan hidup dan perkembangannya di masa datang. Esensi dari pendidikan kecakapan hidup adalah untuk meningkatkan relevansi pendidikan dengan nilai-nilai kehidupan nyata, baik preservatif maupun progresif.

\section{Profil Masyarakat Bajo Desa Bokori}

Desa Bokori Merupakan wilayah pesisir Ibu Kota Kecamatan Soropia dengan luas wilayah 411 Ha sekitar 6,55\% dari luas wilayah Kecamatan Soropia yang di huni 613 Jiwa penduduk dari 169 kepala keluarga. Sebagian besar masyarakat desa ini merupakan suku Bajo. Suku Bajo adalah suku yang tinggal di rumah di atas air dan sehari-harinya menggunakan perahu (lepa). Kata bajo berasal dari nama seorang leluhur mereka yang sangat hebat dalam melaut dan dalam bercocok tanam. Kemudian kampung Karang Bajo adalah nama wilayah keturunan dari Bajo.

Masyarakat Bajo umumnya memiliki bahasa yang sama, yaitu bahasa Bajo yang digunakan sebagai bahasa percakapan dalam keluarga sehari-hari. Bahasa yang digunakan pun saling memahami antara komunitas yang ada dipesisir dari berbagai pulau, seperti pulau Sumatera, Kalimantan, Jawa, Sulawesi, Bali, Nusa Tenggara, Maluku, dan pesisir Papua. Sejumlah kata yang digunakan oleh orang Bajo di Indonesia banyak yang memilikipersamaan dengan bahasa Tagalog dari Filipina, bahkan peneliti lainnya membuktikan bahwa dalam beberapa bahasa Bajo di Indonesia memiliki persamaan kata dengan bahasa Vietnam. ${ }^{8}$

Sumber lain menyebutkan bahwa suku Bajo berasal dari Laut Cina Selatan. Versi lain menyebutkan nenek moyang suku Bajo berasal dari Johor dan Malaysia. Suku Bajo keturunan orang-orang Johor atau keturunan Suku Sameng yang ada di semananjung Malaka, Malaysia yang diperintahkan raja

${ }^{8}$ Poilinggmang, Edwar L, Asal Usul Suku Bajo, h. 5 
untuk mencari putrinya yang kabur dari istana. Orang-orang tersebut mengarungi lautan ke sejumlah tempat sampai ke Pulau Sulawesi. Kabarnya sang puteri berada di Sulawesi, menikah dengan pangeran Bugis kemudian menempatkan rakyatnya di daerah yang sekarang bernama Bajoe. Sedangkan orang-orang yang mencarinya juga lambat laun memilih tinggal di Sulawesi, sebab enggan kembali ke Johor dan kawin dengan orang Bugis. Keturunan mereka lalu menyebar ke segala penjuru wilayah Indonesia dengan perahu. Itulah sebabnya mereka digolongkan suku laut nomaden atau manusia perahu'.

Oleh sebab itu, maka suku Bajo dengan Suku Bugis adalah dua suku yang memiliki ikatan persaudaraan yang sangat erat pada masa itu. Bahkan dikisahkan bahwa:

Pada saat kerajaan Buton akan diserang oleh seorang bajak laut yang berilmu tinggi, yang bernama Labolontio, seseorang yang tubuhnya kebal tidak mampan parang atau pedang dan sejenisnya. Banyak daerah-daerah kerajaan yang ia taklukkan. Dalam perjalanannya menuju kerajaan Buton kapal Labolontio beserta pasukannya hampir tenggelam di perairan Buton Utara, lalu mereka membuang sebagian batu kerikil yang mereka gunakan agar kapal mereka tidak oleng. Sebelum kapal pasukan Labolontio tiba di kerajaan Buton, telah sampai lebih dulu kabar kepada raja Buton pada masa itu. Lalu panglima perang kerajaan Buton mengusulkan kepada sang raja agar segera mengerahkan seluruh pasukan yang mereka miliki untuk melawan Labolontio. Namun sang raja tidak setuju dan mengatakan "saya tidak ingin perajuritku mati sia-sia" sebab sang raja tahu kehebatan ilmu Labolontio. Kemudian sang raja mengatakan "saya hanya butuh dua orang yang nantinya akan dapat mengalahkan Labolontio yakni satu orang dari Suku Bajo dan satunya lagi dari Suku Bugis Selayar. Ketika Labolontio tiba di kerajaan Buton, maka terjadilah pertempuran dan dalam pertempuran tersebut Labolontio kalah dan mati ${ }^{10}$.

Inilah salah satu penyebab sehingga Suku Bajo dengan Suku Bugis secara keseluruhan bersaudara dengan istilah satu komponen yang tidak bisa dipisahkan satu sama lain. Selain menguasai bahasa daerah setempat, orangorang Bugis juga berkomunikasi dengan menggunakan bahasa Bajo.

\footnotetext{
${ }^{9}$ http://www, "Sejarah Keunikan dan Budaya Suku Bajo”, Diakses Tanggal 26 Juni 2016

${ }^{10}$ Marsan, tokoh masyarakat Suku Bajo Desa Bokori Kec. Soropia Kab. Konawe, wawancara, tanggal 27 Juni 2016
} 
Sejak lama masyarakat suku Bajo telah menempati wilayah pesisir pulau Bokori, mereka hidup dengan kearifan dan budaya mereka sendiri. Laut adalah tumpuan utama mereka dalam memenuhi kebutuhan hidup mereka. Pada umumnya penduduk masyarakat desa Bokori Kec. Soropia Kab. Konawe adalah nelayan, selebihnya adalah wiraswasta dan lain-lain. Adapun tingkat pendidikan penduduk masyarakat Desa Bokori pada umumnya di dominasi oleh pendidikan Tingkat Dasar (SD) yakni mencapai 192 orang, SMP yakni mencapai 85 orang, SMA mencapai 115 orang dan lulusan perguruan tinggi sebanyak 7 orang. Sementara itu, kondisi sosial dan budaya masyarakat kurang memadai, hal ini dapat dilihat dari tidak tersedianya sarana pelayanan kesehatan oleh pemerintah untuk meningkatkan pelayanan kesehatan masyarakat, seperti klinik, posyandu dan puskesmas.

\section{D.PENDIDIKAN KECAKAPAN HIDUP PADA REMAJA MASYARAKAT BAJO DI DESA BOKORI \\ D.1 Pemahaman Orang Tua dan Anak tentang Pendidikan Kecakapan Hidup}

Pendidikan kecakapan hidup (life skill) merupakan konsep pendidikan yang bertujuan untuk mempersiapkan remaja untuk belajar agar memiliki keberanian dan kemauan menghadapi masalah hidup dan kehidupan secara wajar tanpa merasa tertekan, dan secara kreatif menemukan solusi serta mampu mengatasinya.

Perkembangan masyarakat dewasa ini menghendaki adanya pembinaan anak didik yang dilaksanakan secara seimbang antara nilai, sikap, pengetahuan, kecerdasan dan keterampilan, kemampuan berkomunikasi dengan masyarakat luas, serta meningkatkan kesadaran terhadap alam lingkungannya. Belajar keterampilan hidup merupakan bagian terpenting sebagai salah satu penunjang masa depan hidup remaja di Desa Bokori. Hal ini sebagaimana diungkapkan berikut:

Belajar atau mengembangkan keterampilan hidup sangat penting bagi anak remaja, karena ini juga bagian dari bekal mereka ketika mereka sudah berkeluarga, minimal mereka bisa bikin sendiri perabotan rumahnya ketika mereka sudah memiliki rumah sendiri seperti lemari, kursi, dan meja. Oleh karena itu, sebagai orang tua sudah seharusnya mendorong dan mengarahkan serta mendukung untuk ikut serta kepada orang yang memiliki keterampilan tersebut, karena di desa ini cukup ada beberapa orang dewasa yang memiliki keterampilan membuat perabot rumah tangga lebih dari itu bahkan ada tukang 
membuat rumah, sehingga lebih khusus lagi di ajarkan mereka keterampilan membuat lemari, kursi, meja dan lain sebagainya ${ }^{11}$.

Orang yang tidak bekerja, orang pensiunan, siswa, mahasiswa, dan sejenisnya tetap memerlukan kecakapan hidup, seperti orang yang bekerja, mereka juga menghadapi berbagai masalah yang harus dipecahkan di dalam hidupnya. Oleh sebab itu, para remaja di Desa Bokori Kec. Soropia Kab. Konawe perlu dibekali dengan kecakapan hidup (life skill) untuk dapat dikembangkan sebaik-baiknya.

Dari sisi remaja, pendidikan kecakapan hidup ini direspon dengan baik oleh mereka sebagaimana keterangan berikut:

Belajar keterampilan hidup merupakan sesuatu keharusan bagi saya, dan harus diberdayakan dengan baik yang nantinya akan menjadi mata pencaharian saya. Karena melihat mata pencaharian di laut makin lama makin surut dan tidak menentu, sehingga saya lebih memilih untuk ikut kursus pertukangan dilembaga pendidikan sehingga saya bisa mepraktekkan pada dunia nyata, yaitu mempu membuat perabot rumah tangga berupa lemari, kursi tempat tidur. Nantinya akan dipasarkan dikota atau pembeli langsung dibangsal. Secara ekonomi, maka sudah bisa membantu untuk menghidupi keluarga ketimbang mencari ikan di laut, itu adalah sesuatu yang tidak pasti. Mencari ikan dilaut merupakan pekerjaan yang mendatangkan uang, tapi namun hanya pekerjaan sampingan saja. Apabila tidak ada yang memesan kursi, maka saya sekali-sekali turun di laut untuk mencari ikan karena ini pekerjaan pertama saya, sebelum memiliki keterampilan membuat kursi, lemari, tempat tidur ${ }^{12}$.

Pemberdayaan keterampilan/kecakapan hidup merupakan strategi penanganan masalah remaja dalam membangun dan mendorong, memberikan motivasi, serta membangkitkan motivasi serta kesadaran akan potensi yang dimiliki remaja di Desa Bokori Kec. Soropia Kab. Konawe.

\section{E. Pelaksanaan Pendidikan Kecakapan Hidup Pada Remaja Masyarakat Bajo}

Praktek pelaksanaan pendidikan kecakapan hidup pada remaja masyarakat Bajo dilakukan dengan cara membiasakan bekerja sejak kecil, mengajarkan teori dan praktek kerja, dan memberikan motivasi. Berikut akan diuraikan satu persatu.

a. Membiasakan bekerja sejak kecil

\footnotetext{
${ }^{11}$ Mustahang, orang tua remaja di Desa Bokori, wawancara, tanggal 20 Juli 2016

${ }^{12}$ Marlan, remaja Desa Bokori, wawancara, tanggal 24 Juni 2016
} 
Salah satu upaya yang dilakukan oleh orang tua khususnya bagi remaja masyarakat Bajo di Desa Bokori Kec. Soropia Kab. Konawe adalah dengan memberikan pendidikan yang berorientasi pada kacakapan hidup (life skills). Sehubungan dengan hal tersebut seorang informan mengatakan:

Langkah pertama yang kami lakukan sebagai orang tua dalam mengajarakan anak-anak membuat kursi, meja dan lemari, adalah membiasakan anak-anak untuk bekerja. Karena kalau sudah terbiasa bekerja, maka mereka tidak akan malas untuk bekerja ${ }^{13}$.

Teknik pembiasaan anak yang dimaksud informan di atas yaitu sejak kecil anak selalu diajak untuk membantu orang tuanya bekerja agar ketika seorang anak sudah beranjak pada tahap pembelajaran, maka akan tumbuh semangat dalam diri mereka untuk selalu belajar dan bekerja.

b. Mengajarkan teori dan praktek kerja

Mengajarkan teori adalah bagian dari proses pendidikan kecakapan hidup (life skills) sebelum melakukan suatu praktek. Setelah mengetahui teori kerja, maka para remaja di Desa Bokori Kec. Soropia Kab. Konawe melakukan praktek, dengan menggunakan alat, seprti cara menggunakan pahat, skap, (skap listrik dan skap tangan), mesin profil dan lain sebagainya, pembelajaran teknik penggunaan alat ini dilakukan sekaligus dengan prakteknya. Hal ini sesuai dengan pemaparan seorang informan bahwa:

Sejak saya berusia 14 tahun saya mulai diajarkan menggunakan alat dalam pembuatan kursi, meja dan lemari, kemudian saya diajarkan cara membuat kursi, meja dan lemari. Setelah saya tahu, saya langsung praktek membuat kursi, meja dan lemari sendiri dan diawasi atau dipandu oleh tukang senior tempat saya belajar, sehingga sedikit demi sedikit dapat saya lakukan sesuai dengan pesanan. oleh karena itu, berkat kesungguhan dan keuletan untuk mengetahui pekerjaan tukang kayu sejak awal niat saya untuk mengetahui keterampilan tersebut maka alhamdulillah mampu melaksanakan pekerjaan itu dengan baik dan sempurna, namun tidak terlepas dari motifasi orang tua dan bimbingan dari orang yang pandai sebagai temapt belajar ${ }^{14}$.

c. Memberikan motivasi

Dalam upaya meningkatkan dan mengembangkan kecakapan hidup pada remaja masyarakat Bajo di Desa Bokori, orang tua yang mengajarkan mereka kecakapan hidup selalu memberikan motivasi dan dorongan kepada mereka agar tumbuh semangat yang tinggi. sebagaimana seorangan informan menyatakan bahwa:

\footnotetext{
${ }^{13}$ Mustahang, orang tua remaja Desa Bokori, wawancara, tanggal 20 Agustus 2016

${ }^{14}$ Tauma, remaja DesaBokori, wawancara, tanggal 26 Agustus 2016
} 
Sebagai pendidik kecakapan hidup sudah sepatutnya kita selalu memberikan dorongan dan motivasi kepada anak-anak remaja untuk selalu meningkatkan dan mengembangkan kecakapan hidup yang mereka miliki. Agar anak-anak remaja kelak memiliki keterampilan hidup yang baik, dan untuk memotivasi mereka tidak harus dikumpulkan kemudian diberikan motivasi. Kita harus pakai trik agar mereka tidak merasa terkekang, yaitu dengan cara mengajaknya ngombrol dan memberikan keyakinan bahwa belajar keterampilan hidup suatu saat akan sangat berguna untuk masa depannya ${ }^{15}$.

\section{F. FAKTOR PENDUKUNG DAN PENGHAMBAT PELAKSANAAN PENDIDIKAN KECAKAPAN HIDUP REMAJA MASYARAKAT BAJO}

\section{F.1 Faktor Pendukung}

Proses pelaksanaan pendidikan kecakapan hidup (life skill) pada remaja di Desa Bokori didukung oleh beberapa faktor, dintaranya adalah faktor jaringan kerja dan faktor pelatih.

1. Jaringan Kerja

Selain melakukan belajar mengajar kecakapan hidup, pengajar dan para remaja yang belajar kecakapan hidup telah membuka jaringan dengan masyarakat Desa Bokori dan masyarakat sekitarnya, misalnya dengan cara menyebarkan pamphlet, sebagaimana diungkapkan berikut:

Supaya proses belajar mengajar kecakapan hidup ini berjalan dengan lancar, maka kami telah membuka jaringan untuk keja sama dengan masyarakat Bokori dan masyarakat sekitarnya khusus membuat kursi, meja dan lemari, kusen, dan pintu rumah. Upaya ini kami lakukan dengan dua cara, yakni berkomunikasi langsung dengan masyarakat dan menyebarkan panplet, dan alhamdulillah upaya ini berhasil, karena dalam satu bulan kadang kami mendapat proyek dua, tiga orang bahkan lebih yang minta untuk dibikinkan kursi, meja lemari, kusen dan pintu rumah ${ }^{16}$.

Upaya ini selain dapat memudahkan proses pelaksanaan pendidikan kecakapan hidup, juga dapat manumbuhkan semangat para remaja di Desa Bokori Kec. Soropia Kab. Konawe untuk lebih serius dan giat belajar.

2. Pelatih

Dalam proses pelaksanaan pendidikan kecakapan hidup, pelatih/pendidik juga merupakan faktor pendukung. Pendidik yang dimaksud disini ialah orang yang ahli khususnya dalam pembuatan kursi, meja dan

\footnotetext{
${ }^{15}$ Talbung, pelatih kecakapan hidup, wawancara, tanggal 02 September 2016

${ }^{16}$ Arifin, remaja Desa Bokori, wawancara, tanggal 2 September 2016
} 
lemari yang mengajarkan para remaja di Desa Bokori sebagaimana yang diungkapkan oleh seorang informan bahwa:

Untuk menciptakan anak-anak remaja yang memiliki kualitas kecakapan yang sangat bagus, maka seorang pendidik juga harus berkualitas dan ahli. Kalau pendidiknya berkualitas memiliki kemampuan yang baik, maka muridnya juga akan berkualitas dan dapat menumbuhkan semangat pada diri anak untuk selalu belajar ${ }^{17}$.

Mengacu pada pernyataan diatas maka dapat dipahami bahwa tenaga pelatih dalam pelaksanaan pendidikan kecakapan hidup (life skill) pada masyarakat Bajo di Desa Bokori Kec. Soropia Kab. Konawe harus memiliki keahlian yang baik untuk membimbing dan memberi pengawasan yang optimal dalam kegiatan pendidikan kecakapan hidup pada remaja.

\section{F.2 Faktor Penghambat}

Selain faktor pendukung, dalam pelaksanaan pendidikan kecakapan hidup pada remaja masyarakat Bokori juga terdapt faktor penghambat, diantaranya adalah faktor pendanaan, sarana dan prasarana, dan alokasi waktu.

1. Faktor pendanaan

Dalam pelaksanaan pendidikan kecakapan hidup di Desa Bokori finansial atau pendanaan juga menjadi faktor penghambat yang paling utama. Hal ini sebagaimana pernyataan yang diungkapkan oleh seorang informan bahwa:

Yang menjadi penghambat dalam pelaksanaan pendidikan kecakapan hidup yang kami laksanakan adalah masalah sangat kurangnya dana untuk keperluan bahan-bahan dan alat. Apalagi seperti saya yang memiliki alat pas-pasan, sementara anak-anak yang saya ajarkan sekarang sebanyak 5 orang $^{18}$.

Berdasarkan keterangan informan diatas maka pendanaan merupakan faktor utama dalam menunjang efektifitas dan efisiensi pengelolaan dan penyelenggaraan pendidikan kecakapan hidup.

2. Sarana dan prasarana

Secara umum berbagai sarana (tempat/ruangan) yang berada di Desa Bokori Kecamatan Soropi Kabupaten Konawe berpotensi untuk dilaksanakan pendidikan kecakapan hidup (life skill), namun dalam pengadaan alat operasionalnya masih belum cukup dengan banyaknya remaja dan sumber dana yang pas-pasan. Selain itu juga adalah minimnya tenaga pengajar sehingga tidak sebanding dengan jumlah peserta didik yang menyebabkan

\footnotetext{
${ }^{17}$ Talbung pelatih kecakapan hidup, wawancara, Tanggal 02 September 2016

${ }^{18}$ Talbung, pelatih kecakapan hidup, wawancara, tanggal 03 September 2016
} 
banyak para remaja tidak terkontrol. Hal ini jika dibiarkan secara terus menerus akan mengakibatkan proses belajar mengajar akan menjadi kurang kondusif dan efisien. Selain itu juga bisa mengurangi motivasi dan kesadaran peserta didik untuk belajar dengan serius agar memiliki keterampilan hidup yang baik.

3. Alokasi waktu

Dalam pelaksanaan pendidikan kecakapan hidup (life skill) remaja masyarakat Bajo di Desa Bokori Kec. Soropia Kab. Konawe terkendala waktu, sebab para remaja memiliki banyak kesibukan lain dan melakukan aktivitas-aktivitas di luar, sehingga mengakibatkan proses pelaksanaan pembelajaran pendidikan kecakapan hidup tersebut sedikit terhambat. Sebagaimana seorang informan menjelaskan bahwa:

Selain faktor finansial dan sarana dan prasarana, faktor padatnya aktifitas yang dilakukan oleh anak remaja di luar juga merupakan faktor penghambat pelaksanaan pendidikan kecakapan hidup, sehingga menyebabkan kegiatan tidak berjalan dengan maksimal. Maka salah satu upaya yang dilakukan dalam menanggulangi hambatan-hambatan dalam pelaksaanaan pendidikan kecakapan hidup, yaitu memaksimalkan kegiatan yang ada dengan cara mengingatkan dan mengarah anak-anak remaja untuk lebih fokus dan giat belajar kecakapan atau keterampilan hidup. ${ }^{19}$

\section{G. PEMANFAATAN PENDIDIKAN KECAKAPAN HIDUP}

Pemanfaatan kecakapan hidup pada anak masyarakat suku Bajo di Desa Bokori yang berorientasi pada keterampilan khusus tidak dimaksudkan untuk mendikte masyarakat tersebut, akan tetapi hanya menawarkan berbagai kemungkinan atau menu yang dapat dipilih sesuai dengan situasi dan kondisi riil masyarakat, baik ditinjau dari keberadaan remaja maupun kehidupan masyarakat sekitar.

Terkait dengan pemanfaatan pendidikan kecakapan hidup (life skill), para remaja di pada umumnya tidak menerapakan kecakapan atau keterampilan yang dimilikinya dengan baik dalam kehidupannya. Hal ini karena kurangnya wawasan dan kesadaran bahwa kecakapan hidup yang mereka miliki dapat menunjang masa depan mereka jika diterapkan atau dimanfaaatkan dengan baik. Menurut salah seorang informan bahwa:

Lebih baik saya jadi nelayan daripada jadi tukang kursi, meja dan lemari karena nelayan lebih banyak hasil atau pendapatannya dari pada usaha permebelan seperti membuat kursi, meja dan lemari. Kalau saya ikut melaut biasanya saya bisa dapat Rp 200.000 dalam

${ }^{19}$ Ibid. 
satu hari, jadi kalau sepuluh hari saya melaut saya bisa dapat Rp2.000.000. Tapi kalau bisnis kursi, meja dan lemari dalam sepuluh hari penghasilannya tidak akan mencapai sampai Rp2.000.000 ${ }^{20}$.

Mencermati pendapat informan di atas, ada sedikit keganjalan atau kekeliruan dalam menilai dan mempertimbangkan hal tersebut, karena pada dasarnya hasil melaut (nelayan) sebenarnya tidak menentu, adakalanya banyak, adakalanya sedikit dan bahkan adakalanya tidak ada sama sekali, apalagi kalau musim keras ombak. Sementara membuat kursi, meja dan lemari hasilnya pasti, terutama di Desa Bokori dan daerah sekitarnya maju pesat dalam tingkat pembangunan rumah dan kantor-kantor yang tentunya sangat membutuhkan perabotan rumah diantaranya kursi, meja dan lemari.

\section{H. PENUTUP}

Masyarakat Desa Bokori Kecamatan Soropia Kabupaten Konawe pada umumnya sangat antusias terhadap pendidikan kecakapan hidup pada remaja. Menurut mereka, pendidikan kecapan hidup adalah hal sangat penting untuk dimiliki oleh para remaja di Desa Bokori, sebab dengan kecakapan tersebut akan dapat menunjang masa depannya serta dapat memecahkan dan mengatasi permasalahan hidup yang dihadapinya.

Pelaksanaan pendidikan kecakapan hidup pada para remaja Desa Bokori cukup baik, hal ini terlihat dari upaya yang dilakukan oleh orang tua remaja dalam menanamkan kecakapan hidup pada para remaja yakni sejak kecil remaja dibiasakan untuk bekerja, diajarakan teori dan praktek kerja dan diberikan motivasi. Dalam pelaksanaan pendidikan kecakapan hidup tersebut ada beberapa faktor yang menjadi pendukung, yaitu adanya jaringan dan kerja sama yang baik dengan masyarakat dan lembaga-lembaga yang ada di wilayah Kecamatan Sopia, dan adanya pendidk/pelatih yang profesional. Selain itu, dalam pelaksanaan pendidikan kecapan hidup juga terdapat hambatan-hambatan, yakni Faktor finansial atau pendanaan yang merupakan faktor yang paling utama, sarana dan prasarana belum maksimal, remaja yang malas dan alokasi waktu. Sayangnya, sebagian besar para remaja di Desa Bokori tidak memanfaatkan kecakapan hidup yang dimilikinya dengan baik, mereka lebih memilih menjadi seorang nelayan. Hal ini disebabkan adanya sudut pandang yang berbeda bahwa nelayan jauh lebih besar penghasilannya daripada menjadi tukang kursi, meja dan lemari.

\section{DAFTAR PUSTAKA}

${ }^{20}$ Sukriadi, remaja Desa Bokori, wawancara, tanggal 04 September 2016 
Anwar. Pendidikan Kecakapan Hidup, Konsep dan Aplikasi. Bandung: CV Alfa Beta, 2004.

Mappiare, Andi. Psikologi Remaja. Surabaya: Usaha Nasional, 1982

Olen, Dale. R. Kecakapan Hidup Pada Anak Bagaimana Mengajarkanya. Diterjemahkan Riyanto Rosa Hasto. Yogyakarta: Kanisius, 1987

Purwanto, Ngalim. Ilmu Pendidikan Teori dan Praktis Edisi II. Bandung: PT Remaja Rosdakarya, 1995.

Sumarni, Sri. Jurnal Ilmu Al-Qur'an Hadits, Kajian Tentang Konsep, Problem dan Prospek Al-Qur'an Hadits. Yogyakarta: IAIN Sunan Kalijaga, 2002.

Santoso, Ananda. Kamus Praktis Bahasa Indonesia Untuk Pelajar dan Umum. Surabaya: Dara Publika, tth.

Soeparwoto, dkk. Psikologi Perkembangan. Cet. V. Semarang: UPT MKK UNNES, 2007.

http://www. "Sejarah Keunikan dan Budaya Suku Bajo", Diakses Tanggal 26 Juni 2016 